\title{
Aberrant Hydroxymethylation In Promoter Cpg Regions of Genes Related to the Cell Cycle and Apoptosis Characterizes Advanced Chronic Myeloid Leukemia Disease, Poor Imatinib Respondents And Poor Survival.
}

Sameer Ahmad Guru ( $\square$ sameerahmadguru@gmail.com )

Maulana Azad Medical College https://orcid.org/0000-0003-0447-0176

Mamta P Sumi

G.B. Pant institute of postgraduate medical education and research

Rashid Mir

University of Tabouk: University of Tabuk

Mirza Masroor Ali Beg

Yeungnam University

Bidhan Chandra Koner

Maulana Azad Medical College

Alpana Saxena

Maulana Azad Medical College

Research article

Keywords: Chronic Myeloid Leukaemia, Imatinib, Epigenetics, Promoter hypermethylation, Cell cycle and apoptosis related genes.

Posted Date: February 15th, 2021

DOI: https://doi.org/10.21203/rs.3.rs-233868/v1

License: (c) (i) This work is licensed under a Creative Commons Attribution 4.0 International License. Read Full License

Version of Record: A version of this preprint was published at BMC Cancer on April 14th, 2022. See the published version at https://doi.org/10.1186/s12885-022-09481-9. 


\section{Abstract}

Background: There is strong evidence that disease progression, drug response and overall clinical outcome of CML disease are not only decided by BCR/ABL1 oncoprotein but depend on accumulation of additional genetic and epigenetic aberrations. DNA hydroxymethylation is implicated in the development of variety of diseases. DNA hydroxymethylation in gene promoters plays an important role in disease progression, drug response and clinical outcome of various diseases. Therefore in this study, we aimed to explore the role of aberrant hydroxymethylation in promoter regions of different tumor suppressor genes in relation to $\mathrm{CML}$ disease progression, response to imatinib therapy and clinical outcome.

We recruited $150 \mathrm{CML}$ patients at different clinical stages of the disease. Patients were followed up for 48 months and haematological/molecular responses were analysed. Haematological response was analysed by peripheral blood smear. BCR/ABL1 specific TaqMan probe based qRT-PCR was used for assessing the molecular response of CML patients on imatinib therapy. Promoter hydroxymethylation of the genes was characterized using MS-PCR.

Results: We observed that promoter hydroxymethylation of cell cycle regulating and apoptosis related genes characterize advanced CML disease and poor imatinib respondents. Although, cytokine signalling (SOCS1) gene was hypermethylated in advanced stages of CML and accumulated in patients with poor imatinib response, but the differences were not statistically significant. Moreover, we found hypermethylation of cell cycle regulating genes ( $\mathrm{p} 14^{\mathrm{ARF}}, \mathrm{RASSF} 1$ and $\mathrm{p} 16^{\mathrm{INK} 4 \mathrm{~A}}$ ) and cytokine signalling gene (SOCS1) significantly associated with poor overall survival of CML patients on imatinib therapy. The results of this study are in agreement of the role of aberrant DNA methylation of different tumor suppressor genes as potential biomarkers of CML disease progression, poor imatinib response and overall clinical outcome.

Conclusion: In this study, we report that promoter hydroxymethylation of cell cycle and apoptosis related genes is a characteristic feature of CML disease progression, defines poor imatinib respondents and poor overall survival of CML patients to imatinib therapy.

\section{Background:}

The study of heritable changes in gene expression that are not encoded in the nucleotide sequence of DNA itself are included in the domain of epigenetics (1). Epigenetic reprogramming one of the most important and critical events in transcription regulation which in turn is mandatory for cell growth, homeostasis and cell fate determination in multicellular organisms (2). Epigenetic processes explain how cells and tissues, bestowed with common genetic material, possess dramatically different phenotypic characteristics. This is achieved by epigenetic regulation of cascades of gene expression patterns unique to each cell type. Much progress has been made over the last couple of decades in revealing phenotypic outcomes associated with post-translational modifications in histone, DNA modifications and non-coding RNAs which are integral parts of epigenetic machinery. There are a number of studies which link 
deregulated DNA methylation in multiple genes with disease progression toward aggressive behaviours or more advanced clinical stages of the disease $(3,4)$. The epigenetic mechanisms have now clearly been established to possess an important role in almost all processes ranging from normal cell development to initiation or progression of diseases, therapeutic response of patients and in the fast adaptive response of cells/organisms to the environmental stimuli (5). This epigenetic gene expression regulation is achieved by chromatin via two ways. First, the accessibility of genomic DNA to transcriptional machinery is directly regulated by the physical properties of chromatin and second, the pattern of DNA binding proteins at a specific locus is regulated by covalent modification of histone N-terminal tails, hence achieving complex regulation of gene expression. DNA methylation and histone modifications are the most studied mechanisms of epigenetic gene regulation $(1,6)$. The most frequent event involved in the pathogenesis of a number of human malignancies is DNA methylation of cytocine to 5methylcytocine, principally at $\mathrm{CpG}$ dinucleotides, in promoter regions of a gene. This epigenetic event is generally associated with inactive transcription (7). The aberrant methylation of $\mathrm{CpG}$ dinucleotides in promoter regions is a common feature associated with various cancers. In particular, in haematological malignancies, de novo methylation inactivates genes associated with DNA-repair, cell cycle regulation and tumor suppressor genes which lead to accumulation of new secondary mutations, a specific feature of disease progression (8).

The importance of epigenetics in the pathogenesis of different human malignancies, especially leukaemia, has gained much recognition during the recent past $(9,10)$. DNA methylation, in addition to playing a vital role in the development of leukaemia, also affects its progression and relapse by altering the expression patterns of various tumor suppressor and cell cycle regulating genes. Methylation of tumor suppressor gene $\mathrm{p} 15$, for example, is the most frequently reported epigenetic event that has been observed in myeloid malignancies. A number of other genes have been reported to be methylated in myeloid malignancies including in chronic myeloid leukaemia (CML) and acute myeloid leukaemia (AML), however the effects of these changes on the development, progression and relapse of disease are not completely understood $(11,12)$.

Chronic myeloid leukaemia is initiated with a single molecular event, the reciprocal translocation between chromosomes 9 and 22, t $(9 ; 22)$, which ultimately results in the formation BCR/ABL1 fusion protein with aberrant tyrosine kinase activity(13). Although being genetically homogenous at the initial phase, a considerable genetic heterogeneity is seen in the clinical course of CML as it progresses at a varying rate from less aggressive chronic phase (CP) to more aggressive accelerated (AP) and blastic (BP) phases. Tyrosine kinase inhibitor; imatinib- the first line treatment for CML patients, is very effective for treating $\mathrm{CP}-\mathrm{CML}$, however considerably poor outcomes are achieved in patients with advanced phase $\mathrm{CML}$ disease(13). The heterogeneity in disease progression and drug (imatinib) response can be attributed to the molecular events including genetic and epigenetic viz, secondary mutations or additional chromosomal aberrations and $\mathrm{CpG}$ methylation patterns or histone modifications that follow BCR/ABL1 fusion (13-16). There are numerous studies which have focussed on elucidation of additional chromosomal abnormalities (ACAs) and other associated genetic events, considered as hallmarks of multistep disease progression in $C M L$ and a characteristic feature of clonal evolution $(17,18)$. A few 
studies have examined the epigenetic events in association with CML disease progression and drug response $(13,13,15)$. However, these studies have been conducted with limited number of total patients with a further decrease in number of subjects at each clinical stage of the disease.

To address the issues of CML disease progression, drug resistance and poor overall clinical outcome with the existing therapies, the secondary aberrations including both genetic and epigenetic, of which methylation of promoter regions of genes bears priority, must be explored. Therefore in this study, we determined the DNA methylation status at CpG dinucleotides of genes associated with apoptosis, cell cycle regulation and cytokine signalling in concert with disease progression, imatinib response and overall survival in chronic myelogenous leukaemia. Here, we report that aberrant promoter hydromethylation of apoptosis related and cell cycle regulating genes is significantly associated with; $\mathrm{CML}$ disease progression to advanced clinical stages, poor imatinib response and poor overall survival as well. We also report that SOCS1 (cytokine signalling) gene promoter methylation did not show any statistical association either with $\mathrm{CML}$ disease progression or imatinib response, but significantly associated with poor overall disease survival. Therefore, the results of our study indicate that hypermethylation at $\mathrm{CpG}$ dinucleotides of apoptosis and cell cycle regulating genes are important drivers of $C M L$ disease progression and characteristic feature of $C M L$ patients with poor imatinib response and poor overall survival.

\section{Methods:}

\section{Patients and healthy donors:}

The enrolled study population included a total of $150 \mathrm{CML}$ patients in different clinical stages of $\mathrm{CML}$ disease and 150 age and gender matched healthy controls. Out of $150 \mathrm{CML}$ patients, we included 100 CML patients who were in chronic phase (CP) and 25 each of accelerated phase (AP) and blast crisis (BC). Institutional Ethics committee (IEC) of Maulana Azad Medical College (MAMC) and associated hospitals approved the study. Peripheral blood/bone marrow samples were collected from the study subjects after written informed consent. The diagnosis of CML patients was made by clinical and haematological examination of peripheral blood/bone marrow. The CML diagnosis was confirmed by molecular detection of BCR/ABL1 fusion gene transcripts using multiplex reverse transcriptase polymerase chain reaction (multiplex RT-PCR) as detailed previously (19-21).

\section{Blood Sampling and Molecular detection of BCR/ABL1 fusion gene transcripts:}

We collected $4 \mathrm{~mL}$ of peripheral blood in Ethylenediaminetetraacetic acid (EDTA) anticoagulant vials. Peripheral Blood Leukocytes (PBLs) were isolated from $4 \mathrm{~mL}$ of blood collected in EDTA anticoagulant vials. RNA was extracted from PBLs through manual extraction method using the Trizol RNA extraction reagent (Amresco Life Sciences, USA). Prior to complimentary DNA (cDNA) synthesis RNA concentration and quality was assessed with an IMPLEN Nanophotometer (IMPLEN, INC. CA). Absorbance at $260 \mathrm{~nm}$ was measured for quantification of nucleic acid concentration. Purity of RNA was assessed by the 
absorbance ratio $260 / 280$ and $260 / 230$. Reverse transcription of the purified RNA was carried out using the Verso cDNA synthesis kit (Thermo Scientific, USA) according to manufacturer's instructions. Briefly, the freshly purified RNA was first incubated at $72{ }^{\circ} \mathrm{C}$ for 10 minutes with random primers and nuclease free water. Following addition of the RNAse inhibitor, reverse transcriptase and CDNA synthesis master mix, the samples were incubated at $42{ }^{\circ} \mathrm{C}$ for 1 hour and finally at $95^{\circ} \mathrm{C}$ for 5 minutes to terminate the reaction. The cDNA was chilled at $4{ }^{\circ} \mathrm{C}$ for 10 minutes in the thermo cycler itself before transferring it to $-80^{\circ} \mathrm{C}$ storage for further analysis. The amount of RNA used was $200 \mathrm{ng} / \mu \mathrm{L}$ for each sample in cDNA synthesis.

Next the CDNA synthesized was used to amplify $B C R / A B L 1$ fusion gene transcripts using tetra primer multiplex RT-PCR. Tetra-primer multiplex RT-PCR system is able to detect different $B C R / A B L 1$ fusion gene transcript variants viz. $b_{2} / a_{2}, b_{3} / a_{2}, e 1 a 2$. The primer sequences used for the detection of $B C R / A B L 1$ fusion gene transcripts were adopted as previously mentioned (22). The primer sequences with annealing temperature used in this PCR system are given in Table 1. The original PCR thermal cycling profile was used with an annealing temperature of $64^{\circ} \mathrm{C}$ as mentioned in Table 1 . The healthy control subjects were confirmed to have normal $\mathrm{CBC}$ and negative for $B C R / A B L 1$ fusion gene transcripts.

Table 1

Primers used in multiplex PCR for detection of BCR/ABL1 fusion gene transcripts (19):

\begin{tabular}{|lll|}
\hline Primer code & Primer Sequence & Annealing temperature \\
\hline A & 5'-ATAGGATCCTTTGCAACCGGGTCTGAA-3' & \multirow{2}{*}{$64^{\circ} \mathrm{C}$} \\
\cline { 1 - 2 } C & 5'-ACAGAATTCCGCTGACCATCAATAAG-3' & \\
\cline { 1 - 2 } D & 5'-ACCGCATGTTCCGGGACAAAAG-3' & \\
\hline
\end{tabular}

\section{Patient Follow-up And Evaluation Of Molecular And Hematologic Response:}

The patients were followed-up for 48 months following imatinib therapy. Examination of bone marrow biopsies/aspirates was undertaken at enrolment if indicated after assessing the clinical situation in detail. The diagnosis of different clinical stages of CML disease was made on the basis of the guidelines mentioned by European Leukaemia Net (ELN)(23). The imatinib dosages were administrated for the patients based on their hematologic and non-hematologic toxicities, ranging from $200 \mathrm{mg}$ to $600 \mathrm{mg}$ daily for CP, $300 \mathrm{mg}$ to $800 \mathrm{mg}$ for AP and $600 \mathrm{mg}$ to $800 \mathrm{mg}$ for BP. Patients were monitored after every fifteen days and drug response/toxicity evaluated after initiation of imatinib therapy. 
The Complete Hematologic Response (CHR) was evaluated as defined by examining the patients for complete blood counts (WBC count below $10 \times 10^{9} / \mathrm{L}$ ), the absence of immature cells (blast cells, myelocytes and promyelocytes) using microscopic assessment of peripheral blood and other clinical features like splenomegaly. Moreover, molecular response was assessed once after the initiation of imatinib therapy. An undetectable BCR/ABL1 fusion gene transcripts was defined as; $\mathrm{MR}^{4}, \mathrm{MR}^{4.5}$ with BCR-ABL1 expression $\leq 0.01 \%$ and $\leq 0.0032 \%$ respectively compared to the base line levels, whereas a $\leq$ $0.1 \%$ reduction in BCR/ABL1 transcript titters compared to the base line levels was defined as Major Molecular Response (MMR). No Molecular Response (NMR) was also defined when an increasing changes in BCR-ABL1/ ABL1 were detected.

\section{DNA isolation and Analysis of methylation pattern at CpG dinucleotide sites of different genes:}

The samples were processed for isolation of DNA after confirming CML diagnosis by detection of $B C R / A B L 1$ fusion gene transcripts with multiplex RT-PCR. The isolation of DNA was carried out using commercially available DNA isolation kit (Gene Aid, India), according to the manufacturer's instructions as previously described (20). The quality and integrity of DNA was checked by $1 \%$ agarose gel stained with $0.5 \mu \mathrm{g} / \mathrm{mL}$ Ethidium Bromide (EtBr, stock $10 \mathrm{mg} / \mathrm{mL}$ ), prepared in $1 X$ Tris base, acetic acid and EDTA (TAE, pH-8.3) and quantified by NanoDrop spectrophotometer (Washington, DC, USA).

A standardized genomic DNA concentration $(50 \mu \mathrm{g} / \mu \mathrm{L})$ was modified with sodium bisulphite using EZDNA methylation kit (Zymo Research, India). Bisulphite-modified DNA samples were stored at $-80^{\circ} \mathrm{C}$ until used. The methylation of various genes at $\mathrm{CpG}$ dinucleotides of promoter regions was analysed using methylation specific polymerase chain reaction (MS-PCR). The primer sequences used for characterization of $\mathrm{CpG}$ methylation are mentioned in Table 2 below. The amplification program of MSPCR consisted of 40 cycles with $95^{\circ} \mathrm{C}$ as initial denaturation temperature and 40 cycles of denaturation at $95^{\circ} \mathrm{C}$ for 45 seconds, annealing temperatures (specific for each gene), and extension of $72^{\circ} \mathrm{C}$. A final extension temperature of $72^{\circ} \mathrm{C}$ was used for final amplification. The PCR amplicons were resolved on $2 \%$ EtBr stained agarose gel prepared in 1X TAE buffer. 
Table 2

Primers used to study promoter hypermethylation of different genes

\begin{tabular}{|c|c|c|}
\hline Gene & Name & Primer sequence \\
\hline \multirow[t]{4}{*}{ DAPK1 } & Unmethylated forward & 5'-GGAGGATAGTTGGATTGAGTTAATGTT-3' \\
\hline & Unmethylated Reverse & 5'-САААТСССТСССАААСАССАА-3' \\
\hline & Methylated forward & 5'-GGATAGTCGGATCGAGTTAACGTC-3' \\
\hline & Methylated Reverse & 5'-CССTCCCAAACGCCGA-3' \\
\hline \multirow[t]{4}{*}{ RIZ-1 } & Unmethylated forward & 5'-TGGTGGTTATTGGGTGATGGT-3' \\
\hline & Unmethylated Reverse & 5'-ACTATTTCACCAACCCCAAGA-3' \\
\hline & Methylated forward & 5'-GTGGTGGTTATTGGGCGACGGC-3' \\
\hline & Methylated Reverse & 5'-GCTATTTCGCCGACCCCGACG-3' \\
\hline \multirow[t]{4}{*}{ P16INK4A } & Unmethylated forward & 5'-TTATTAGAGGGTGGGGTGGATTGT-3' \\
\hline & Unmethylated Reverse & 5'-CAACCCCAAACCACAACCATAA - 3' \\
\hline & Methylated forward & 5'-TTATTAGAGGGTGGGGCGGATCGC-3' \\
\hline & Methylated Reverse & 5'-GACCCCGAACCGCGACCGTAA - 3' \\
\hline \multirow[t]{4}{*}{ RASSF1A } & Unmethylated forward & 5'-GGGTTTTGCGAGAGCGCGT-3' \\
\hline & Unmethylated Reverse & 5'-GCTAACAAACGCGAACCG-3' \\
\hline & Methylated forward & 5'- GGTTTTGTGAGTGTGTTTAGT-3' \\
\hline & Methylated Reverse & 5'-САCTAACACACAAACCAAACA-3' \\
\hline \multirow[t]{4}{*}{ socs1 } & Unmethylated forward & 5'-TCGTTCGTACGTCGATTATC-3' \\
\hline & Unmethylated Reverse & 5'-AAAAAAATACCCACGAACTCG-3' \\
\hline & Methylated forward & 5'-TATTTTGTTTGTATGTTGATTATTG-3' \\
\hline & Methylated Reverse & 5'-AAACTCAACACACAACCACTC-3' \\
\hline \multirow[t]{4}{*}{ p14ARF $\mathrm{ARF}$} & Unmethylated forward & 5'-TTTTGGTGTTAAAGGGTGGTGTAGT-3' \\
\hline & Unmethylated Reverse & 5'- CACAAAAACCCTCACTCACAACAA-3' \\
\hline & Methylated forward & 5'-GTGTTAAAGGGCGGCGTAGC-3' \\
\hline & Methylated Reverse & 5'- AAAACCCTCACTCGCGACGA-3' \\
\hline
\end{tabular}

\section{Statistical Analysis And Data Interpretation:}


The differences among CML patients with different clinical stage and imatinib response groups at each CpG site were measured by the Fisher's exact test to assess whether the differences existed varied significantly. Differences in survival of patients showing hypo-and hypermethylation at the CpG sites analysed in this study, were calculated using Kaplan-Meier method. The comparisons that showed a $p$ value less than 0.05 were considered statistically significant. The statistical comparisons of categorical data were performed using GraphPad Prism 5 and survival comparisons were done using SPSS 20.0 software packages.

\section{Results:}

\section{Study population:}

The diagnosis of suspected CML patients who were presented at Lok Nayak Hospital, New Delhi, from February 2015 to January 2019, was confirmed by the molecular detection of $B C R / A B L 1$ fusion gene transcripts, as discussed in methodology section, in the Leukaemia Diagnosis Laboratory, Department of Biochemistry, Maulana Azad Medical College (MAMC) and Associated Hospitals, New Delhi. Atypical CML patients were excluded from the study. The final cohort included $150 \mathrm{CML}$ patients in different clinical stages and 150 age and gender matched healthy controls. Demographic features and base line disease characteristics and haematological parameters of the study population are shown in Tables 3, 4 and 5 below.

Table 3

CML patients' demographic features and imatinib dose:

\begin{tabular}{|c|c|c|c|}
\hline $\begin{array}{l}\text { Age/Sex of } \\
\text { CML patients }\end{array}$ & $\begin{array}{l}\text { CML Patients } \\
(n=150)\end{array}$ & $\begin{array}{l}\text { Imatinib } 200 \mathrm{mg} \text { to } 600 \mathrm{mg} \text { OD } \\
\text { dose group }(n=59)\end{array}$ & $\begin{array}{l}\text { Imatinib } 600 \mathrm{mg} \text { to } 800 \mathrm{mg} \text { OD } \\
\text { dose group }(n=91)\end{array}$ \\
\hline \multicolumn{4}{|c|}{ Age (year) median (range) } \\
\hline $\begin{array}{l}\text { All CML } \\
\text { patients }\end{array}$ & $38(15-80)$ & $38(15-80)$ & $40(16-66)$ \\
\hline $\begin{array}{l}\text { Age } \leq \\
38 \text { years }\end{array}$ & $30(15-38)$ & $30(15-38)$ & $30(16-38)$ \\
\hline Age $>38$ years & $47(40-80)$ & $48(40-80)$ & $47(40-66)$ \\
\hline \multicolumn{4}{|l|}{ Sex, n (\%) } \\
\hline Male & $89(59)$ & $37(41.5)$ & $52(58.5)$ \\
\hline Female & $61(41)$ & $22(36)$ & $39(64)$ \\
\hline
\end{tabular}


Table 4

Clinical and disease characteristics of CML patients at base line:

$\begin{array}{llll}\begin{array}{l}\text { Disease } \\ \text { characteristics }\end{array} & \begin{array}{l}\text { CML Patients } \\ (n=150)\end{array} & \begin{array}{l}\text { Imatinib 400-mg OD dose } \\ \text { group }(n=59)\end{array} & \begin{array}{l}\text { Imatinib 600-mg OD dose } \\ \text { group }(n=91)\end{array}\end{array}$

\section{Splenomegaly, $\mathrm{n}(\%)$}

$\begin{array}{llll}\text { No } & 57(38) & 27(47) & 30(53) \\ \text { Yes } & 93(62) & 32(34) & 61(66)\end{array}$

Hepatomegaly, n (\%)

$\begin{array}{llll}\text { No } & 113(75) & 44(39) & 69(61) \\ \text { Yes } & 37(25) & 15(40.5) & 22(59.5)\end{array}$

Table 5

Haematological parameters of CML patients at base line:

$\begin{array}{llll}\text { Characteristics } & \begin{array}{l}\text { CML Patients }(\mathrm{n} \\ =150)\end{array} & \begin{array}{l}\text { Imatinib 400-mg OD dose } \\ \text { group }(n=59)\end{array} & \begin{array}{l}\text { Imatinib 600-mg OD dose } \\ \text { group }(n=91)\end{array}\end{array}$

Total Leukocyte Count $/ \mathrm{mm}^{3}$ (TLC)

$\begin{array}{llll}\text { Median } & 1,42,200 & 1,54000 & 1,25,800 \\ \text { Range } & 3,460-9,64,000 & 19,520-9,64000 & 3,460-6,73,650\end{array}$

Hemoglobin (gm/dL)

$\begin{array}{llll}\text { Median } & 9.3 & 9 & 9.8 \\ \text { Range } & 4.7-17.2 & 4.7-13.4 & 5-17.2\end{array}$

Platelets (Lacs $\left./ \mathrm{mm}^{3}\right)$

$\begin{array}{llll}\text { Median } & 2.95 & 2.29 & 3.75 \\ \text { Range } & 1.78-15.11 & 1.79-2.97 & 1.78-15.11\end{array}$

Assessment of haematological and molecular responses of CML patients to imatinib therapy:

The CML patients (150) included in the study were followed for 48 months. Mean duration of follow- up was $23.7 \pm 6.68$ months and ranged from 3 months to 48 months. During the follow-up of these $150 \mathrm{CML}$ patients, complete haemogram (Hb, TLC, DLC, platelet count and ESR) was assessed at regular intervals. The haematological response to imatinib was analyzed to assess whether the patients achieved Complete Hematological Response (CHR) and the time to achieve CHR was noted (THR). Mean THR was $5.6 \pm 5.02$ months (range 1-12 months). Each patient's haematological response was based on patient's best response during the course of treatment till 12th month. Of the 100 chronic phase, 25 accelerated phase and 25 blast crisis CML patients 97 (97\%), 21 (84\%) and 17 (68\%) achieved Complete Hematologic 
Response respectively (Table 6). Therefore, the rate of haematological response was more in case of CP$\mathrm{CML}$ patients followed by AP-CML and then BC-CML patients. Moreover, the duration of achieving haematological response was lesser in patients with CP-CML disease (within 6 months of follow-up) than those patients with advanced stage (AP and BC) of the disease (between 8 to 12 months of the followup). Relapse of the disease was defined as increase in white blood count $>2000 / \mathrm{mm}^{3}$, platelet count $\geq$ $600,000 / \mathrm{mm}^{3}$, appearance of blasts in peripheral blood (24).

Table 6

Time taken for achievement of complete hematological response

(CHR).

\begin{tabular}{|llll|}
\hline & 3 months & 6 months & 12 months \\
\hline No. of patients & 150 & 150 & 150 \\
\hline CHR achieved, $\mathbf{n}(\%)$ & $97(65 \%)$ & $104(69 \%)$ & $135(90 \%)$ \\
\hline CHR not achieved, $\mathbf{n ( \% )}$ & $53(35 \%)$ & $46(31 \%)$ & $15(10 \%)$ \\
\hline
\end{tabular}

Molecular Response (BCR-ABL1/ABL \%) was assessed once, either at 6 months or at 12 months after the beginning of imatinib therapy and response was categorized as Major Molecular Response (MMR) with BCR-ABL1 expression of $\leq 0.1 \%$, and further deep molecular response (MR) as; $\mathrm{MR}^{4}, \mathrm{MR}^{4.5}$ with BCR$A B L 1$ expression $\leq 0.01 \%$ and $\leq 0.0032 \%$ respectively compared to the base line levels, and no molecular response (NMR) as defined in methodology section. The molecular response to imatinib with 400 and 800 OD dose arms are shown in Table 7. The rates of major molecular response (MMR) at 6 months and 12 months were $12.66 \%$ and $39.33 \%$ respectively, while the 6 month and 12 month rates of deeper molecular responses with $\mathrm{MR}^{4}$ and $\mathrm{MR}^{4.5}$ log reduction were respectively $6.00 \%$ vs $5.33 \%$ and $15.33 \%$ vs $12.00 \%$ (Table 7).

Table 7

Achievement of molecular response.

\begin{tabular}{|c|c|c|c|c|}
\hline $\begin{array}{l}\text { Time duration After } \\
\text { initiation of Treatment } \\
\text { (months) }\end{array}$ & Response & $\begin{array}{l}\text { Imatinib 400-mg } \\
\text { OD dose group (n } \\
=59 \text { ) }\end{array}$ & $\begin{array}{l}\text { Imatinib 800-mg } \\
\text { OD dose group (n } \\
=91 \text { ) }\end{array}$ & $\begin{array}{l}\text { Total proportion } \\
\text { of patients }(n= \\
150)\end{array}$ \\
\hline 6 months & \multirow{2}{*}{$\begin{array}{l}\text { MMR } \\
\mathrm{n}(\%)\end{array}$} & $7(11.86)$ & $12(13.18)$ & $19(12.66)$ \\
\hline 12 months & & $17(28.81)$ & $34(37.36)$ & $51(34.00)$ \\
\hline 6 months & \multirow{2}{*}{$\mathrm{MR}^{4} \mathrm{n}(\%)$} & $4(6.78)$ & $5(5.49)$ & $9(6.00)$ \\
\hline 12 months & & $8(13.56)$ & $14(15.38)$ & $22(14.66)$ \\
\hline 6 months & \multirow{2}{*}{$\begin{array}{l}\mathrm{MR}^{4.5} \\
\mathrm{n}(\%)\end{array}$} & $3(5.08)$ & $5(5.49)$ & $8(5.33)$ \\
\hline 12 months & & $7(11.86)$ & $11(12.08)$ & $18(12.00)$ \\
\hline
\end{tabular}


The patients were then further followed and hematologic assessments (haemoglobin, white blood cells, platelets, percentage of blasts, percentage of eosinophils and percentage of basophils) and presence/absence of hepatosplenomegaly were performed every fifteen days during the course of treatment. The patients were then grouped into three categories (Table 8) according to ELN guidelines(23); I) Optimal response; associated with long term best outcome, II) Warning; included those patients who required more frequent monitoring so as to allow timely modifications of the therapy in case of developing treatment toxicities and III) Failure; defined those patients who were having stable and increasing disease as evidenced by persistence of $\mathrm{CP}$ and progression to advanced phases (AP and BC) of CML disease respectively. Of the 150 patients, $23(15.33 \%)$ patients failed to achieve response to imatinib therapy and of these 23 patients, $17(11.33 \%)$ had primary failure and 6 patients (4.00\%) had secondary failure to treatment.

Table 8

Categorization of patients on the basis of molecular response

\begin{tabular}{|llll|}
\hline & OPTIMAL & WARNING & FAILURE \\
\hline No.of patients,n (\%) & $109(72.66)$ & $18(12)$ & $23(15.33)$ \\
\hline
\end{tabular}

\section{Promoter CpG dinucleotide hypermethylation of apoptosis and cell cycle regulatory genes is associated with disease progression of CML to advanced stages:}

A total of six genes including apoptosis related genes (DAPK1 and RIZ1), cell cycle regulating genes ( $16^{\text {INK4A }}$, RASSF1A and p14 ${ }^{\mathrm{ARF}}$ ) and Suppressor of Cytokine Signalling (SOCS1) gene were analysed for promoter $\mathrm{CpG}$ dinucleotide methylation in white blood cell DNA from $150 \mathrm{CML}$ patients in different clinical stages of the disease and in matched healthy control subjects by MS-PCR. To reveal the methylation pattern of these genes in patients with CML in CP $(n=100), A P(n=25)$ and BC $(n=25)$, fisher's exact test was applied for comparison between different groups. It was found that the frequency of promoter $\mathrm{CpG}$ dinucleotide methylation of all the six genes studied was significantly more in chronic, accelerated and blastic phases in comparison to age and gender matched healthy control subjects.

Moreover, it was observed that frequency of promoter $\mathrm{CpG}$ dinucleotide methylation patterns of apoptosis (DAPK1 and RIZ1) and cell cycle related genes ( $\mathrm{p} 16^{\text {INK4 }}$, RASSF1A and p14 ${ }^{\text {ARF }}$ ) was significantly more in advanced stages of CML disease compared to early chronic phase disease. In addition, an increasing promoter $\mathrm{CpG}$ dinucleotide methylation frequency was observed in case of SOCS1 gene in accelerated and blastic phases of the CML disease than chronic phase but the differences did not reach statistical significance. A statistical analysis of methylation patterns of the different genes studied and comparison among patients of different clinical stages is described in Table 9 and Fig. 1. 
Table 9

Promoter $\mathrm{CpG}$ dinucleotide methylation of different genes in CML patients and association with different clinical stages:

\begin{tabular}{|c|c|c|c|c|c|}
\hline Gene & Stage of disease & Unmethylated n(\%) & Methylated $n(\%)$ & Chi-Square & p-value \\
\hline \multirow[t]{3}{*}{ RASSF1 } & CP-CML & $94(94 \%)$ & $6(6 \%)$ & \multirow[t]{3}{*}{25.87} & \multirow[t]{3}{*}{$<0.0001$} \\
\hline & AP-CML & $17(68 \%)$ & $8(32 \%)$ & & \\
\hline & BC-CML & $14(56 \%)$ & $11(44 \%)$ & & \\
\hline \multirow[t]{3}{*}{ socs1 } & CP-CML & 94 (94\%) & $6(6 \%)$ & \multirow[t]{3}{*}{2.95} & \multirow[t]{3}{*}{0.23} \\
\hline & AP-CML & $22(88 \%)$ & $3(12 \%)$ & & \\
\hline & BC-CML & $21(84 \%)$ & $4(16 \%)$ & & \\
\hline \multirow[t]{3}{*}{ DAPK1 } & CP-CML & $71(71 \%)$ & $29(29 \%)$ & \multirow[t]{3}{*}{11.67} & \multirow[t]{3}{*}{0.003} \\
\hline & AP-CML & $13(52 \%)$ & $12(48 \%)$ & & \\
\hline & BC-CML & $9(36 \%)$ & $16(64 \%)$ & & \\
\hline \multirow[t]{3}{*}{ RIZ1 } & CP-CML & $93(93 \%)$ & $7(7 \%)$ & \multirow[t]{3}{*}{6.40} & \multirow[t]{3}{*}{0.04} \\
\hline & AP-CML & $21(84 \%)$ & $4(16 \%)$ & & \\
\hline & BC-CML & 19 (76\%) & $6(24 \%)$ & & \\
\hline \multirow[t]{3}{*}{ P16INK4A } & CP-CML & $79(79 \%)$ & $21(21 \%)$ & \multirow[t]{3}{*}{18.23} & \multirow[t]{3}{*}{0.0001} \\
\hline & AP-CML & $15(60 \%)$ & $10(40 \%)$ & & \\
\hline & BC-CML & $9(36 \%)$ & $16(64 \%)$ & & \\
\hline \multirow[t]{3}{*}{ P14ARF } & CP-CML & $94(94 \%)$ & $6(6 \%)$ & \multirow[t]{3}{*}{10.98} & \multirow[t]{3}{*}{0.004} \\
\hline & AP-CML & $18(72 \%)$ & $7(28 \%)$ & & \\
\hline & BC-CML & $20(80 \%)$ & $5(20 \%)$ & & \\
\hline
\end{tabular}

Promoter CpG hypermethylation of apoptosis and cell cycle regulatory genes is associated with poor molecular response in $\mathrm{CML}$ patients:

Next hydroxymethylation of promoter $\mathrm{CpG}$ dinucleotides of the six genes studied was analysed among patients grouped on the basis of their response to imatinib therapy. It was found that promoter hypermethylation of cell cycle regulating (RASSF1, p16 ${ }^{\mathrm{INK} 4}$ and p14 ${ }^{\mathrm{ARF}}$ ) and apoptosis related (RIZ-1) genes was a characteristic feature of patients in warning and failure groups as the proportion of patients, with promoter $\mathrm{CpG}$ dinucleotide hydroxymethylation of these genes, was found to be significantly more in 
imatinib failure and warning groups as compared to optimal response group. The proportion of patients, with promoter $\mathrm{CpG}$ dinucleotide methylation of DAPK1 (an apoptosis related) gene, was observed to be more in warning group (50\%) followed by imatinib failure group $(47.8 \%)$ and then by optimal response category $(34.0 \%)$, but the difference was not statistically significant $(p=0.24)$. Further, the corresponding proportion of patients with promoter $\mathrm{CpG}$ dinucleotide methylation of cytokine signalling gene SOCS1 was $7.4 \%, 11.1 \%$ and $13.1 \%$ in optimal, warning and failure groups, however, this progressive increase in proportion of patients with SOCS1 promoter $\mathrm{CpG}$ dinucleotide hydroxymethylation from optimal response category to warning and failure did not reach any statistical significance. The association of molecular response of $\mathrm{CML}$ patients to imatinib and promoter $\mathrm{CpG}$ dinucleotide hydroxymethylation is depicted in Table 10 and Fig. 2.

Table 10

Promoter $\mathrm{CpG}$ dinucleotide methylation of different genes in $\mathrm{CML}$ patients and association with molecular response:

\begin{tabular}{|c|c|c|c|c|c|}
\hline Gene & Response & Unmethylated (\%) & Methylated (\%) & Chi-Square & p-value \\
\hline \multirow[t]{3}{*}{ RASSF1 } & Optimal & $98(89.9 \%)$ & $11(10.1 \%)$ & \multirow[t]{3}{*}{13.35} & \multirow[t]{3}{*}{0.001} \\
\hline & Warning & $13(72.2 \%)$ & $5(27.8 \%)$ & & \\
\hline & Failure & $14(60.9 \%)$ & $9(39.1 \%)$ & & \\
\hline \multirow[t]{3}{*}{ Socs1 } & Optimal & $101(92.6 \%)$ & $8(7.4 \%)$ & \multirow[t]{3}{*}{0.94} & \multirow[t]{3}{*}{0.62} \\
\hline & Warning & $16(88.9 \%)$ & $2(11.1 \%)$ & & \\
\hline & Failure & $20(86.9 \%)$ & $3(13.1 \%)$ & & \\
\hline \multirow[t]{3}{*}{ DAPK1 } & Optimal & $72(66.0 \%)$ & $37(34.0 \%)$ & \multirow[t]{3}{*}{2.80} & \multirow[t]{3}{*}{0.24} \\
\hline & Warning & $9(50.0 \%)$ & $9(50.0 \%)$ & & \\
\hline & Failure & $12(52.2 \%)$ & $11(47.8 \%)$ & & \\
\hline \multirow[t]{3}{*}{ RIZ1 } & Optimal & $107(98.2 \%)$ & $2(1.8 \%)$ & \multirow[t]{3}{*}{38.28} & \multirow[t]{3}{*}{$<0.001$} \\
\hline & Warning & $13(72.2 \%)$ & $5(27.8 \%)$ & & \\
\hline & Failure & $13(56.5 \%)$ & $10(43.5 \%)$ & & \\
\hline \multirow[t]{3}{*}{ P16INK4A } & Optimal & $86(79.0 \%)$ & $23(21.0 \%)$ & \multirow[t]{3}{*}{25.16} & \multirow[t]{3}{*}{$<0.0001$} \\
\hline & Warning & $11(61.1 \%)$ & $7(38.9 \%)$ & & \\
\hline & Failure & $6(26.1 \%)$ & $17(73.9 \%)$ & & \\
\hline \multirow[t]{3}{*}{ P14ARF } & Optimal & $101(92.7 \%)$ & $8(7.3 \%)$ & \multirow[t]{3}{*}{10.63} & \multirow[t]{3}{*}{0.005} \\
\hline & Warning & $12(66.7 \%)$ & $6(33.3 \%)$ & & \\
\hline & Failure & $19(82.6 \%)$ & $4(17.4 \%)$ & & \\
\hline
\end{tabular}




\section{Kaplan-Meier Analysis for overall survival related to hydroxymethylation of various genes:}

After a follow-up of 48 months, estimated overall survival for $\mathrm{CpG}$ dinucleotide methylation of the studied genes was analysed. This was observed that overall survival significantly differed in patients with hypermethylation as compared to those with hypomethylation of cell cycle regulated genes: $\mathrm{p} 16^{\text {INK4A }}$ (median survival for hypomethylation $=44$ moths; $\mathrm{Cl}=43.30-44.69$ and median survival for hypermethylation $=43$ months; $\mathrm{Cl}=35.80-50.20 ; \mathrm{p}=0.0001$ ), RASSF1 (median survival for hypomethylation $=44$ months; $\mathrm{Cl}=43.62-44.36$ and median survival for hypermethylation $=42$ months; $\mathrm{Cl}=36.53-47.46 ; \mathrm{p}=0.0001$ ) and $\mathrm{p} 14^{\mathrm{ARF}}$ (median survival for hypomethylation $=44$ months; $\mathrm{Cl}=43.51-$ 44.48 and median survival for hypermethylation $=42$ months; $\mathrm{Cl}=31.09-52.90 ; \mathrm{p}=0.01$ ). Also, hypomethylation of Suppressor of Cytokine Signalling (SOCS1) gene was found to be associated with better survival (median survival for hypomethylation $=44$ months; $\mathrm{Cl}=43.61-44.38$ and median survival for hypermethylation $=28$ months; $\mathrm{Cl}=25.22-31.17 ; \mathrm{p}<0.0001)$. However, promoter methylation of apoptosis related genes including DAPK1 and RIZ1 did not exhibit any significant differences in overall survival of patients with hypo and hypermethylation status $(p=0.09 ; p=0.05$ respectively). The results are depicted in Fig. 3.

\section{Discussion:}

The complexity of the relation between a genotype and phenotype is increasing with the advancement of cell and molecular biology techniques. The phenotype is the ultimate product of not only the number of genes but also of the intricate regulatory networks that affect or are associated with gene expression. In order to completely understand the pathology of both malignant and non-malignant disorders, it is imperative to focus on various regulatory networks associated with gene expression. This would ultimately benefit in finding new candidate markers for initiation, development or progression of the disease and identifying novel targets for therapeutic intervention as well. Epigenetic signatures are the basis of this regulatory network and methylation of $\mathrm{CpG}$ dinucleotides constitutes an important mechanism of gene silencing.

The mechanisms which contribute to progression of $\mathrm{CML}$ disease and drug response vary to a considerable extent and have not been clearly understood. The various events that have, till now, been found as culprits for the progression of CML to advanced clinical stages and drug response may be categorized at cellular and molecular levels. The culprits at cellular level include increased proliferation, decreased apoptosis, differentiation halt, abnormal immune surveillance while activation of oncogenes, tumor suppressor gene inactivation, genomic instability, impaired DNA repair mechanisms among others are the molecular culprits (25). The control of most of the above cited events can be attributed to changes in the genes that are at the heart of that particular event. Apoptosis, differentiation, DNA repair for example are controlled by the activity of genes related to these processes and among the various mechanisms, DNA methylation in the promoter regions of a gene is one of the important processes that 
controls gene expression. DNA hyper and hypomethylation are respectively associated with decreased and ectopic expression of the genes. Moreover, DNA methylation at $\mathrm{CpG}$ dinucleotides could also influence differential promoter usage influencing gene expression patterns (26).

In this study, we report promoter $\mathrm{CpG}$ hydroxymethylation status of various genes including cell cycle regulating genes, apoptosis related genes and cytokine signalling genes that act as the drivers and controlling arms of most of the processes cited above as mechanisms of CML disease progression and drug response. To find the association of methylation status of the genes with $\mathrm{CML}$ disease progression and drug response, we analysed the methylation differences among CML patients in different clinical stages and among age and gender matched healthy controls. It was found that CML patients possessed significant hypermethylation in all the genes studied, in comparison to healthy control subjects. Moreover, the proportion of CML patients with hypermethylation of promoter $\mathrm{CpG}$ dinucleotides of cell cycle regulating and apoptosis genes was significantly more in advanced disease (AP and BC) stages in comparison to early CML (CP) disease subjects. In addition, proportion of patients with promoter hypermethylation of cytokine signalling gene (SOCS1) was also found to be more in advanced CML disease compared to early CML disease, however, the differences were not statistically significant. These findings of our current study confirm and extend the reports of previous studies $(3,27-29)$. Methylation of cell cycle regulating genes like $\mathrm{p} 16^{\mathrm{INK} 4 \mathrm{~A}}$ has been found to be associated with progression of $\mathrm{CML}$ disease and $\mathrm{p} 16^{\mathrm{INK} 4 \mathrm{~A}}$ promoter hypermethylation is reported to be associated with late stage $\mathrm{CML}$ disease in other studies $(29,30)$. Moreover, progression to lymphoid blast crisis has been found to be associated with homozygous deletions of $\mathrm{p} 16^{\text {INK4A }}$ gene $(30,31)$. RASSF1 promoter methylation has been seen in CML-derived erythroleukaemia K562 cell line but not in CML patients at different clinical stages (32). However, this is not in accordance to our study, we report that RASSF1 methylation is associated with CML disease progression based on the finding that proportion of patients with RASSF1 methylation in advanced $\mathrm{AP}$ and $\mathrm{BC} C \mathrm{CML}$ disease was more than that of $\mathrm{CP}$ disease. This contradiction in our results to those of Avramouli A et al, 2009, might be because of smaller number of patients $(n=31)$ studied (32). One of the frequently altered cell cycle regulating genes is $\mathrm{p} 14^{\mathrm{ARF}}$ which has been reported to be inactivated through various mechanisms viz, mutations, deletions and DNA methylation in variety of malignancies of diverse origin (33). $\mathrm{p} 16^{\mathrm{INK} 4 \mathrm{~A}}$ and $\mathrm{p} 14^{\mathrm{ARF}}$ inactivation through promoter methylation are reported to be important events associated with accelerated phase of CML disease (34). However, the results need to be validated in a large cohort of CML patients in all the three clinical stages since the total number of subjects in which the reports have been investigated by E Nagy et al, 2003, was too small ( $n=$ 30). In this study, the same results have been replicated in comparatively large number of subjects. Further, we have previously found that methylation of $\mathrm{p} 16^{\mathrm{INK} 4 \mathrm{~A}}$ gene is one of the primary events in $\mathrm{CML}$ disease progression (35). The epigenetic changes of apoptosis related genes are reported to be associated with progression of both solid tumors and hematologic malignancies as well (36). Promoter methylation of DAPK1, for example, is a characteristic feature of breast cancer (37). In this study, the promoter methylation of apoptosis related gene DAPK1 was found to be related to accelerated phase and blast crisis. However, it is reported that promoter methylation of RIZ1, another apoptosis related gene, is not a characteristic feature of advanced CML disease which is in contrast to our findings in this study 
which could again be attributed to the smaller number of subjects included in the previous study (27). RIZ1 gene inactivation during blast crisis occurs through epigenetic silencing and has been suggested as a predictive marker for imatinib resistance and CML disease progression (38). Reduced expression of RIZ1 and DAPK1 due to promoter hypermethylation has been reported in other malignancies as well, such as cervical cancer/ cervical neoplasia $(39,40)$, thyroid tumorigenesis $(41)$, stomach carcinogenesis $(42)$, cervical cancer (39), lung cancer patients(43-45). Therefore, the above discussion of promoter methylation and disease progression of $\mathrm{CML}$ to advanced phases supports the idea of considering the use of epigenetic drugs along with tyrosine kinase inhibitor (TKI) therapy. This may help a significant number of CML patients in better management of the disease.

Although, in addition to constitutively active tyrosine kinase; $B C R / A B L 1$, the root cause of $C M L$ pathogenesis, a considerable amount of factors come into play when one talks of CML progression, prognosis and drug response. During the recent couple of decades; we have witnessed a huge surge for the identification of mechanisms and factors that decide patients' response to TKI therapy. A variety of factors including gene amplification, additional chromosomal aberrations, point mutations, epigenetic changes, to name a few, have been cited as mechanisms underlying drug response in CML disease. These factors might help in defining the outcome of therapy and decide the treatment strategy of a patient; however each of these factors and mechanisms need to be extensively studied and validated by conducting further studies so that they may help in predicting drug response and prognosis among patients with $\mathrm{CML}$ disease. In this study, we evaluated hydroxymethylation status at promoter CpG dinucleotides of six genes in concert with imatinib response. It was observed that methylation at promoter CpG dinucleotide regions of cell cycle regulating genes including RASSF1, p16 ${ }^{\text {INK4A }}$ and p14 ARF and apoptosis related genes DAPK1 and RIZ-1 are characteristics of poor respondents of imatinib drug. We found significant association of increased methylation patterns of the above cited genes with poor imatinib response as judged by the proportion of patients with hypermethylation of the genes to be more in warning and failure groups as compared to optimal response group. The identification of methylation of apoptosis related DAPK1 and RIZ1 genes in concert with drug response and prognosis is utmost important. We observed that DAPK1 and RIZ1 promoter methylation is significantly associated with poor imatinib response in CML patients. Methylation of DAPK1 is reported in other cancers like gastric cancer $(46-50)$. There are contradictory reports regarding methylation of DAPK1 in concert with drug response and prognosis for example no correlation of DAPK1 methylation was found with prognosis in ovarian cancer (51) and non small cell lung cancer(52). However, there are reports suggesting a strong association of DAPK1 hypermethylation with poor disease specific survival and therapy response (53). Hypermethylation of RIZ1 has been reported for its inactivation and silencing (54). In one of the studies from our lab, we have reported that RIZ1 promoter methylation increases progressively in CML disease in advanced phases and that its expression may be a cause, among others, for poor drug response in CML patients on imatinib treatment (55). In another study, we have reported that decrease in RIZ1 gene is responsible for increased IGF1 expression in K562 CML blast crisis cell line and in advanced disease CML patients (56). Yet another report from our lab has observed that inactivation of RIZ1 gene by insertion/deletion polymorphism and promoter hypermethylation is associated with CML disease 
progression and imatinib resistance (57). In the present study, we observed that promoter hypermethylation of RIZ1 is significantly more frequent in advanced CML disease compared to early disease and that RIZ1 hypermethylation at promoter $\mathrm{CpG}$ dinucleotides is a characteristic feature of poor imatinib respondents. But we could not find any statistical difference in proportion of patients having hyper and hypomethylation of RIZ1 gene promoter in relation to overall survival. RIZ1 reduced expression has been reported in other haematological malignancies (58). In adult acute lymphoblastic leukaemia, reduced RIZ1 gene expression has been found to be associated with leukemogenesis. Inactivation of RIZ1 is a characteristic feature of T-ALL (58). However, further studies are required for elucidation of the inactivation mode of RIZ1 and its intricate role in development and progression of different types of malignancies and drug response. RASSF1A promoter methylation is speculated to influence drug sensitivity of tumors like non small cell lung carcinoma (59), esophageal squamous carcinoma tumorigenesis (60), breast cancer patients (61). In addition, there are reports suggesting utilization of RASSF1A methylation for monitoring response to adjuvant therapy in the clinic as RASSF1A methylation depletion has been found to be linked with good response to adjuvant regimens(62). Apparent methylation patterns of RASSF1A gene is reported as biomarker of lung cancer diagnosis, treatment and prognosis(63). RASSF1A and its epigenetics have gained much attention due to its increasing occurrence in diverse cancer types. Promoter methylation of RASSF1A, which is preceded by histone modifications, has been reported as an epigenetic candidate marker in a variety of cancers with diverse origin. There are reports which suggest that its epigenetic abrogation may promote expression of RASSF1C which is a putative oncogenic isoform (64). However, some studies discuss RASSF1A methylation in non small cell lung carcinoma and associate it with good response (65). Therefore, a better understanding of the significance of RASSF1A methylation pattern in various cancer types becomes imperative for its clinical and drug behaviour role. Our results indicate that RASSF1A hypermethylation characterizes poor imatinib response and poor survival of CML patients treated with imatinib. $\mathrm{p} 16^{\mathrm{INK} 4 \mathrm{a}}$ expression has been found to be associated with poor prognosis in ER-positive, PR-negative and HER2-negative tumors and hence reported as a predictive prognostic indicator to predict treatment response for hormonal therapy (66). Hypermethylation of $\mathrm{p} 16^{\mathrm{INK} 4 \mathrm{~A}}$ and $\mathrm{p} 14^{\mathrm{ARF}}$ has been suggested to possess predictive properties for a variety of clinicopathological outcomes. Moreover, p14 ${ }^{\mathrm{ARF}}$ and $\mathrm{p} 16^{\mathrm{INK} 4 \mathrm{~A}}$ gene inactivation has been reported in development of colon carcinoma (67), cervical cancer (68), hematological malignancies(69). It is suggested that methylation profile of $\mathrm{p} 14^{\mathrm{ARF}}$ and $\mathrm{p} 16^{\mathrm{INK} 4 \mathrm{~A}}$ might be playing an important role in distinct subsets of colon carcinoma(70). The observation from our present study that hypermethylation of these two genes accumulate in patients with poor drug response and poor overall survival and the reports from previous studies discussed above indicate that methylation status of $\mathrm{p} 16^{\mathrm{INK} 4 \mathrm{~A}}$ and $\mathrm{p} 14^{\mathrm{ARF}}$ can definitely be used as promising candidate predictors of response to therapy and clinical outcome.

Suppressor of cytokine signaling1 (SOCS1) gene has been recognised as tumor suppressor gene and found to be related to lymphatic metastasis and disease progression of liver cancer (71). Silencing of SOCS1 by methylation is reported in hepatocellular carcinoma and other tumors like cervical cancer (72), hepatoblastoma(73), esophageal squamous cancers(74), melanoma, squamous cell carcinoma of the head and neck, pancreatic carcinoma and breast and ovarian cancer (75). SOCS1 gene methylation has 
been reported to cause gene silencing which is accompanied by downstream JAK/STAT signalling and promotion of cell proliferation in acute myeloid leukaemia (76). In this study, although we found a higher proportion of patients with SOCS1 methylation in advanced disease stages and poor imatinib respondents, but the difference was not statistically significant. Our results are slightly different from the previous study by Ta Chih Liu et al (2003) (77) which reports that SOCS1 gene methylation plays an important role in the pathogenesis of $\mathrm{CML}$ disease progression. This discrepancy might be attributed to the environmental effects and ethnicity of the cases being studied. The methylation status of the DNA and histone proteins depends on ethnicity of population (78). However, we did observe that hydroxyrmethylation of SOCS1 gene was significantly associated with poor overall survival of CML patients on imatinib therapy. Therefore, we suggest that there is need of more studies to conduct for studying the exact role of SOCS1 methylation and expression patterns that will provide more detailed insight of the role of SOCS1 methylation in CML disease progression and imatinib response. The major limitation of our study was that we did not characterize the methylation pattern of the genes quantitatively. Another limitation of our study was that we were not able to include homogenous number of patients in each clinical stage of the disease.

Based on the present study and from the above discussion, it may be suggested that hydroxymethylation of cell cycle regulating and apoptosis related genes are the main characteristics of a variety of malignancies including haematological ones. Therefore, more accurate and site specific methylation pattern of genomic loci should be focussed in future studies. These studies would benefit to identify the methylation patterns of the genes involved in cancer development, progression and prognosis and illustrate the feasibility of epigenome target therapy.

\section{Conclusion:}

The results of this study indicate that hydroxymethylation of promoter regions of cell cycle regulating and apoptosis related genes may be an important marker of CML disease progression, defines poor imatinib respondents and characterizes poor overall clinical outcome of CML patients on imatinib therapy. Hence, our study supports the rationale of using demethylating agents in combination with tyrosine kinase inhibitor therapy for better clinical outcome.

\section{Abbreviations}

Chronic Myeloid Leukaemia (CML), Philadelphia Chromosome (Ph Chromosome), Tyrosine Kinase Inhibitors (TKIs), Breakpoint Cluster Region (BCR), Abelson Leukaemia Viral Oncogene (ABL).

\section{Declarations}

- Ethics approval and consent to participate: 
Institutional Ethics committee (IEC) of Maulana Azad Medical College (MAMC) and associated hospitals approved the study. Peripheral blood/bone marrow samples were collected from the study subjects after written informed consent.

\section{- Consent for publication:}

Written informed consent was obtained from the participants with $\geq 18$ years of age before they were recruited for the study. The written informed consent was obtained from patients $\geq 18$ years of age and from parents/legal guardians of the patients with $<18$ years of age.

\section{- Availability of data and materials:}

The datasets presented in the current study can be provided on special requests by the corresponding author.

\section{- Competing interests}

None of the authors or any funding agency have any competing interests.

\section{- Funding:}

Indian Council of Medical Research (ICMR), India funded this research by sanctioning grant to Dr. Sameer Ahmad Guru under Senior Research Fellowship (SRF) scheme, during his graduate studies.

\section{- Authors' contributions}

SAG has conducted all the experiments of the study, compiled the data, analysed the data, interpreted the results and wrote the first draft of the manuscript. MPS collected the blood samples, helped in conducting the experiments of the study, compilation and analysis of the data. ARM supervised the execution of the research work related to the manuscript and performed peripheral blood haematological tests. MMAB helped in follow-up of the patients and maintenance of follow-up data. BCK revised the statistical analyses part and language of the manuscript. AS contributed in generating concept of the work and research design. Extensively revised the final manuscript submitted.

- Acknowledgements: The authors are highly grateful to Multidisciplinary Research Unit (MRU) and Department of Biochemistry, Maulana Azad Medical College, New Delhi, India for providing lab space and instrumentation for carrying out the research work. We thank all the subjects for giving their consent to be included in the study. Our special thanks are also extended to the technical and sanitary staff of the MRU and Department of Biochemistry for keeping good sanitary conditions in the labs.

\section{- Authors' information (optional):}


Sameer Ahmad Guru: Scientist-I at Multidisciplinary Research Unit (MRU), Maulana Azad Medical College, New Delhi.

Mamta P Sumi: Scientist-B at Department of Biochemistry, G.B. Pant Institute of Postgraduate Medical Education and Research (GIPMER), New Delhi

Abdul Rashid Mir: Assistant Professor, Faculty of Applied Medical Sciences, Division of Molecular Biology, Prince Fahd Bin Sultan Research chair , University of Tabuk, Kingdom of Saudi Arabia, Tabuk 71491.

Mirza Masroor Ali Beg: Postdoctoral Scientist at Department of Medical Biotechnology, Yeungnam University, Republic of Korea.

Bidhan Chandra koner: Director Professor, Department of Biochemistry and Nodal officer of Multidisciplinary Research Unit (MRU), Maulana Azad Medical College, New Delhi, India.

Alpana Saxena: Director Professor, Head of the Department of Biochemistry, Maulana Azad Medical College, New Delhi, India.

- Foot notes: N/A

\section{References}

1. Egger G, Liang G, Aparicio A, Jones PA. Epigenetics in human disease and prospects for epigenetic therapy. Nature. 2004 May;429(6990):457-63.

2. The H3K27 demethylase Utx regulates somatic and germ cell epigenetic reprogramming. - Abstract Europe PMC [Internet]. [cited 2020 Jul 12]. Available from: https://europepmc.org/article/med/22801502.

3. Jelinek J, Gharibyan V, Estecio MRH, Kondo K, He R, Chung W, et al. Aberrant DNA methylation is associated with disease progression, resistance to imatinib and shortened survival in chronic myelogenous leukemia. PloS One. 2011;6(7):e22110.

4. Patterns of DNMT1 Promoter Methylation in Patients with Acute Lymphoblastic Leukemia. - Abstract - Europe PMC [Internet]. [cited 2020 Jul 12]. Available from:

https://europepmc.org/article/med/28989582.

5. Prezioso C, Orlando V. Polycomb proteins in mammalian cell differentiation and plasticity. FEBS Lett. 2011 Jul 7;585(13):2067-77.

6. Reik W. Stability and flexibility of epigenetic gene regulation in mammalian development. Nature. 2007 May 24;447(7143):425-32.

7. Santini V, Kantarjian HM, Issa JP. Changes in DNA methylation in neoplasia: pathophysiology and therapeutic implications. Ann Intern Med. 2001 Apr;3(7):573-86. 134(. 
8. Nagarajan RP, Costello JF. Molecular epigenetics and genetics in neuro-oncology. Neurother J Am Soc Exp Neurother. 2009 Jul;6(3):436-46.

9. Toyota M, Kopecky KJ, Toyota MO, Jair KW, Willman CL, Issa JP. Methylation profiling in acute myeloid leukemia. Blood. 2001 May 1;97(9):2823-9.

10. Clinical implications of aberrant DNA methylation patterns in acute myelogenous leukemia. Abstract - Europe PMC [Internet]. [cited 2020 Jul 20]. Available from: https:// europepmc.org/article/med/16231140.

11. Herman JG, Jen J, Merlo A, Baylin SB. Hypermethylation-associated inactivation indicates a tumor suppressor role for p15INK4B. Cancer Res. 1996 Feb 15;56(4):722-7.

12. Daskalakis M, Nguyen TT, Nguyen $C$, Guldberg P, Köhler G, Wijermans $P$, et al. Demethylation of a hypermethylated P15/INK4B gene in patients with myelodysplastic syndrome by 5-Aza-2'deoxycytidine (decitabine) treatment. Blood. 2002 Oct;15(8):2957-64. 100(.

13. Nelkin BD, Przepiorka D, Burke PJ, Thomas ED, Baylin SB. Abnormal methylation of the calcitonin gene marks progression of chronic myelogenous leukemia. Blood. 1991 Jun 1;77(11):2431-4.

14. Angel A. Processing of sensory information. Prog Neurobiol. 1977;9(1-2):1-122.

15. Issa JP, Zehnbauer BA, Kaufmann SH, Biel MA, Baylin SB. HIC1 hypermethylation is a late event in hematopoietic neoplasms. Cancer Res. 1997 May 1;57(9):1678-81.

16. Strathdee G, Holyoake TL, Sim A, Parker A, Oscier DG, Melo JV, et al. Inactivation of HOXA genes by hypermethylation in myeloid and lymphoid malignancy is frequent and associated with poor prognosis. Clin Cancer Res Off J Am Assoc Cancer Res. 2007 Sep;13(17)(1):5048-55.

17. Cortes JE, Talpaz M, Giles F, O’Brien S, Rios MB, Shan J, et al. Prognostic significance of cytogenetic clonal evolution in patients with chronic myelogenous leukemia on imatinib mesylate therapy. Blood. 2003 May 15;101(10):3794-800.

18. O'Dwyer ME, Mauro MJ, Blasdel C, Farnsworth M, Kurilik G, Hsieh Y-C, et al. Clonal evolution and lack of cytogenetic response are adverse prognostic factors for hematologic relapse of chronic phase CML patients treated with imatinib mesylate. Blood. 2004 Jan;15(2):451-5. 103(.

19. Mir R, Ahmad I, Javid J, Zuberi M, Yadav P, Shazia R, et al. Simple multiplex RT-PCR for identifying common fusion BCR-ABL transcript types and evaluation of molecular response of the a2b2 and a2b3 transcripts to Imatinib resistance in north Indian chronic myeloid leukemia patients. Indian J Cancer. $2015 \mathrm{Jul}$ 1;52(3):314.

20. PDGFRa promoter polymorphisms. and expression patterns influence risk of development of imatinib-induced thrombocytopenia in chronic myeloid leukemia: A study from India - Sameer Ahmad Guru, Rashid Mir, Musadiq Bhat, Imtiyaz Najar, Mariyam Zuberi, Mamta Sumi, Mirza Masroor, Naresh Gupta, Alpana Saxena, 2017 [Internet]. [cited 2020 Jul 20]. Available from: https://journals.sagepub.com/doi/full/10.1177/1010428317713857.

21. Guru SA, Sumi MP, Mir R, Waza AA, Bhat MA, Zuberi M, et al. Ectopic PD-L1 expression in JAK2 (V617F) myeloproliferative neoplasm patients is mediated via increased activation of STAT3 and STAT5. Hum Cell. 2020 Oct 1;33(4):1099-111. 
22. Technical aspects and clinical applications of measuring BCR-ABL1. transcripts number in chronic myeloid leukemia - Foroni - 2009 - American Journal of Hematology - Wiley Online Library [Internet]. [cited $2020 \mathrm{Jul}$ 20]. Available from: https://onlinelibrary.wiley.com/doi/abs/10.1002/ajh.21457.

23. Baccarani M, Deininger MW, Rosti G, Hochhaus A, Soverini S, Apperley JF, et al. European LeukemiaNet recommendations for the management of chronic myeloid leukemia: 2013. Blood. 2013 Aug;8(6):872-84. 122(.

24. Radich JP, Kopecky KJ, Appelbaum FR, Kamel-Reid S, Stock W, Malnassy G, et al. A randomized trial of dasatinib $100 \mathrm{mg}$ versus imatinib $400 \mathrm{mg}$ in newly diagnosed chronic-phase chronic myeloid leukemia. Blood. 2012 Nov 8;120(19):3898-905.

25. Shet AS, Jahagirdar BN, Verfaillie CM. Chronic myelogenous leukemia: mechanisms underlying disease progression. Leukemia. 2002 Aug;16(8):1402-11.

26. Bert SA, Robinson MD, Strbenac D, Statham AL, Song JZ, Hulf T, et al. Regional activation of the cancer genome by long-range epigenetic remodeling. Cancer Cell. 2013 Jan;14(1):9-22. 23(.

27. Aberrant methylation in promoter-associated $\mathrm{CpG}$ islands of multiple genes in chronic myelogenous leukemia blast crisis [Internet]. [cited 2020 Jul 20]. Available from: https://www.spandidospublications.com/10.3892/ol.2011.419.

28. Maupetit-Mehouas S, Court F, Bourgne C, Guerci-Bresler A, Cony-Makhoul P, Johnson H, et al. DNA methylation profiling reveals a pathological signature that contributes to transcriptional defects of CD34 + CD15- cells in early chronic-phase chronic myeloid leukemia. Mol Oncol. 2018;12(6):814-29.

29. Qian J, Wang Y-L, Lin J, Yao D-M, Xu W-R, Wu C-Y. Aberrant methylation of the death-associated protein kinase 1 (DAPK1) CpG island in chronic myeloid leukemia. Eur J Haematol. 2009 Feb;82(2):119-23.

30. Sill H, Goldman JM, Cross NC. Homozygous deletions of the p16 tumor-suppressor gene are associated with lymphoid transformation of chronic myeloid leukemia. Blood. $1995 \mathrm{Apr}$ 15;85(8):2013-6.

31. Serra A, Gottardi E, Della Ragione F, Saglio G, Iolascon A. Involvement of the cyclin-dependent kinase4 inhibitor (CDKN2) gene in the pathogenesis of lymphoid blast crisis of chronic myelogenous leukaemia. Br J Haematol. 1995 Nov;91(3):625-9.

32. Avramouli A, Tsochas S, Mandala E, Katodritou E, loannou M, Ritis K, et al. Methylation status of RASSF1A in patients with chronic myeloid leukemia. Leuk Res. 2009 Aug;33(8):1130-2.

33. Ruas M, Peters G. The p16INK4a/CDKN2A tumor suppressor and its relatives. Biochim Biophys Acta. 1998 Oct;14(2):F115-77. 1378(.

34. Nagy E, Beck Z, Kiss A, Csoma E, Telek B, Kónya J, et al. Frequent methylation of p16INK4A and p14ARF genes implicated in the evolution of chronic myeloid leukaemia from its chronic to accelerated phase. Eur J Cancer. 2003 Nov;39(16)(1):2298-305.

35. Ah I. Inactivation of P16 (INK4a) Gene by Promoter Hypermethylation is Associated with Disease Progression in Chronic Myelogenous Leukaemia. J Carcinog Mutagen [Internet]. 2013 [cited 2020 Jul 20];04(02). Available from: https://www.omicsonline.org/inactivation-of-p16-ink4a-gene-by-promoter- 
hypermethylation-is-associated-with-disease-progression-in-chronic-myelogenous-leukaemia-21572518.1000141. php?aid=14013.

36. Hu X-T, He C. Recent progress in the study of methylated tumor suppressor genes in gastric cancer. Chin J Cancer. 2013 Jan;32(1):31-41.

37. Xiang T-X, Yuan Y, Li L-L, Wang Z-H, Dan L-Y, Chen Y, et al. Aberrant promoter CpG methylation and its translational applications in breast cancer. Chin J Cancer. 2013 Jan;5(1):12-20. 32(.

38. Ahmad Najar I. Inactivation of RIZ1 Gene by Promoter Hypermethylation is Associated with Disease Progression and Resistance to Imatinib in Indian Chronic Myelogenous Leukemia Patients, First Study from India. J Cancer Sci Ther [Internet]. 2013 [cited 2020 Jul 20];05(02). Available from: https://www.omicsonline.org/inactivation-of-riz1-gene-by-promoter-hypermethylation-is-associatedwith-disease-progression-1948-5956.1000183.php?aid=10537.

39. Hy C, Y G, G L. DNA methylation of the RIZ1 tumor suppressor gene plays an important role in the tumorigenesis of cervical cancer [Internet]. Vol. 15, European journal of medical research. Eur J Med Res; 2010 [cited $2020 \mathrm{Jul}$ 20]. Available from: https://pubmed.ncbi.nlm.nih.gov/20159667/.

40. Wang X, Cui N, Liu X, Ma J, Zhu Q, Guo S, et al. Identification of DAPK1 Promoter Hypermethylation as a Biomarker for Intra-Epithelial Lesion and Cervical Cancer: A Meta-Analysis of Published Studies, TCGA, and GEO Datasets. Front Genet [Internet]. 2018 [cited 2020 Jul 20];9. Available from: https://www.frontiersin.org/articles/10.3389/fgene.2018.00258/full.

41. Lal G, Padmanabha L, Smith BJ, Nicholson RM, Howe JR, O'Dorisio MS, et al. RIZ1 is epigenetically inactivated by promoter hypermethylation in thyroid carcinoma. Cancer. 2006 Dec 15;107(12):27529.

42. Oshimo Y, Oue N, Mitani Y, Nakayama H, Kitadai Y, Yoshida K, et al. Frequent epigenetic inactivation of RIZ1 by promoter hypermethylation in human gastric carcinoma. Int J Cancer. 2004;110(2):212-8.

43. Tang X, Khuri FR, Lee JJ, Kemp BL, Liu D, Hong WK, et al. Hypermethylation of the death-associated protein (DAP) kinase promoter and aggressiveness in stage I non-small-cell lung cancer. J Natl Cancer Inst. 2000 Sep;20(18):1511-6. 92(.

44. Kim DH, Nelson HH, Wiencke JK, Christiani DC, Wain JC, Mark EJ, et al. Promoter methylation of DAP-kinase: association with advanced stage in non-small cell lung cancer. Oncogene. $2001 \mathrm{Mar}$ 29;20(14):1765-70.

45. Harden SV, Tokumaru Y, Westra WH, Goodman S, Ahrendt SA, Yang SC, et al. Gene promoter hypermethylation in tumors and lymph nodes of stage I lung cancer patients. Clin Cancer Res Off $\mathrm{J}$ Am Assoc Cancer Res. 2003 Apr;9(4):1370-5.

46. Kim WS, Son HJ, Park JO, Song SY, Park C. Promoter methylation and down-regulation of DAPK is associated with gastric atrophy. Int J Mol Med. 2003 Dec;12(6):827-30.

47. Schildhaus H-U, Kröckel I, Lippert H, Malfertheiner P, Roessner A, Schneider-Stock R. Promoter hypermethylation of p16INK4a, E-cadherin, 06-MGMT, DAPK and FHIT in adenocarcinomas of the esophagus, esophagogastric junction and proximal stomach. Int J Oncol. 2005 Jun;26(6):1493-500. 
48. Waki T, Tamura G, Sato M, Terashima M, Nishizuka S, Motoyama T. Promoter methylation status of DAP-kinase and RUNX3 genes in neoplastic and non-neoplastic gastric epithelia. Cancer Sci. 2003 Apr;94(4):360-4.

49. Tang LP, Cho CH, Hui WM, Huang C, Chu KM, Xia HHX, et al. An inverse correlation between Interleukin-6 and select gene promoter methylation in patients with gastric cancer. Digestion. 2006;74(2):85-90.

50. Chang M-S, Uozaki H, Chong J-M, Ushiku T, Sakuma K, Ishikawa S, et al. CpG island methylation status in gastric carcinoma with and without infection of Epstein-Barr virus. Clin Cancer Res Off $\mathrm{J}$ Am Assoc Cancer Res. 2006 May 15;12(10):2995-3002.

51. K I JAYS. H N, K O, N Y. Promoter methylation status and expression of TMS1 gene in human epithelial ovarian cancer. Cancer Sci. 2004 Jan;95(1)(1):40-3.

52. Zöchbauer-Müller S, Fong KM, Virmani AK, Geradts J, Gazdar AF, Minna JD. Aberrant promoter methylation of multiple genes in non-small cell lung cancers. Cancer Res. 2001 Jan 1;61(1):249-55.

53. Raveh T, Kimchi A. DAP kinase-a proapoptotic gene that functions as a tumor suppressor. Exp Cell Res. 2001 Mar 10;264(1):185-92.

54. Hasegawa Y, Matsubara A, Teishima J, Seki M, Mita K, Usui T, et al. DNA methylation of the RIZ1 gene is associated with nuclear accumulation of p53 in prostate cancer. Cancer Sci. 2007;98(1):326.

55. Sumi MS, Ahmad G, Bhat MA, Rashid AR, Zuberi M, Gupta N, et al. RIZ1 Gene Promoter Methylation Increases with Progression of Chronic Myeloid Leukaemia to Advanced Phases. Blood. 2017 Dec 7;130(Supplement 1):1608-1608.

56. Guru S, Bhat M, Seethy A, Zuberi M, Sumi M, Singh P, et al. 01-13-4RIZ1 negatively regulates IGF-1 expression in chronic myeloid leukemia. 2016.

57. Inactivation of RIZ1 Gene. by RIZ1 Pro704 Insertion-Deletion Polymorphism and Promoter Hypermethylation is Associated With Disease Progression and Resistance to Imatinib in Indian Chronic Myelogenous Leukemia Patients - Clinical Lymphoma, Myeloma and Leukemia [Internet]. [cited 2020 Sep 29]. Available from: https://www.clinical-lymphoma-myelomaleukemia.com/article/S2152-2650(14)00228-6/abstract.

58. Shimura H, Mori N, Wang Y-H, Okada M, Motoji T. Aberrant methylation and decreased expression of the RIZ1 gene are frequent in adult acute lymphoblastic leukemia of T-cell phenotype. Leuk Lymphoma. 2012 Aug;53(8):1599-609.

59. Zhai X, Li S-J. Methylation of RASSF1A and CDH13 genes in individualized chemotherapy for patients with non-small cell lung cancer. Asian Pac J Cancer Prev APJCP. 2014;15(12):4925-8.

60. Du Z, Ma K, Sun X, Li A, Wang H, Zhang L, et al. Methylation of RASSF1A gene promoter and the correlation with DNMT1 expression that may contribute to esophageal squamous cell carcinoma. World J Surg Oncol. 2015 Apr;8:13:141.

61. Jezkova E, Zubor P, Kajo K, Grendar M, Dokus K, Adamkov M, et al. Impact of RASSF1A gene methylation on the metastatic axillary nodal status in breast cancer patients. Oncol Lett. 2017 
Jul;14(1)(1):758-66.

62. Fiegl H, Millinger S, Mueller-Holzner E, Marth C, Ensinger C, Berger A, et al. Circulating tumor-specific DNA: a marker for monitoring efficacy of adjuvant therapy in cancer patients. Cancer Res. 2005 Feb 15;65(4):1141-5.

63. Mengxi D, Qian W, Nan W, Xiaoguang X, Shijun L. Effect of DNA methylation inhibitor on RASSF1A genes expression in non-small cell lung cancer cell line A549 and A549DDP. Cancer Cell Int. 2013 Sep;8(1):91. 13(.

64. Malpeli G, Innamorati G, Decimo I, Bencivenga M, Nwabo Kamdje AH, Perris R, et al. Methylation Dynamics of RASSF1A and Its Impact on Cancer. Cancers. 2019 Jul;11(7):959.

65. Fischer JR, Ohnmacht U, Rieger N, Zemaitis M, Stoffregen C, Manegold C, et al. Prognostic significance of RASSF1A promoter methylation on survival of non-small cell lung cancer patients treated with gemcitabine. Lung Cancer Amst Neth. 2007 Apr;56(1):115-23.

66. Goyal A, Sahu RK, Kumar M, Sharma S, Qayyum S, Kaur N, et al. p16 promoter methylation, expression, and its association with estrogen receptor, progesterone receptor, and human epidermal growth factor receptor 2 subtype of breast carcinoma. J Cancer Res Ther. 2019 Sep;15(5):1147-54.

67. Al-Kaabi A, van Bockel LW, Pothen AJ, Willems SM. p16INK4A and p14ARF gene promoter hypermethylation as prognostic biomarker in oral and oropharyngeal squamous cell carcinoma: a review. Dis Markers. 2014;2014:260549.

68. Jha AK, Nikbakht M, Jain V, Capalash N, Kaur J. p16(INK4a) and p15(INK4b) gene promoter methylation in cervical cancer patients. Oncol Lett. 2012 Jun;3(6):1331-5.

69. Taniguchi T, Chikatsu N, Takahashi S, Fujita A, Uchimaru K, Asano S, et al. Expression of p16INK4A and p14ARF in hematological malignancies. Leukemia. 1999 Nov;13(11):1760-9.

70. Burri N, Shaw P, Bouzourene H, Sordat I, Sordat B, Gillet M, et al. Methylation silencing and mutations of the p14ARF and p16INK4a genes in colon cancer. Lab Investig J Tech Methods Pathol. 2001 Feb;81(2):217-29.

71. Chu P-Y, Yeh C-M, Hsu NC, Chang Y-S, Chang J-G, Yeh K-T. Epigenetic alteration of the SOCS1 gene in hepatocellular carcinoma. Swiss Med Wkly. 2010;140:w13065.

72. Sobti RC, Singh N, Hussain S, Suri V, Nijhawan R, Bharti AC, et al. Aberrant promoter methylation and loss of suppressor of cytokine signalling- 1 gene expression in the development of uterine cervical carcinogenesis. Cell Oncol Dordr. 2011 Dec;34(6):533-43.

73. Sakamoto LHT, DE Camargo B, Cajaiba M, Soares FA, Vettore AL. MT1G hypermethylation: a potential prognostic marker for hepatoblastoma. Pediatr Res. 2010 Apr;67(4):387-93.

74. Hussain S, Singh N, Salam I, Bandil K, Yuvaraj M, Akbar Bhat M, et al. Methylation-mediated gene silencing of suppressor of cytokine signaling-1 (SOCS-1) gene in esophageal squamous cell carcinoma patients of Kashmir valley. J Recept Signal Transduct Res. 2011 Apr;31(2):147-56.

75. Marini A, Mirmohammadsadegh A, Nambiar S, Gustrau A, Ruzicka T, Hengge UR. Epigenetic Inactivation of Tumor Suppressor Genes in Serum of Patients with Cutaneous Melanoma. J Invest Dermatol. 2006 Feb 1;126(2):422-31. 
76. Zhang X-H, Yang L, Liu X-J, Zhan Y, Pan Y-X, Wang X-Z, et al. Association between methylation of tumor suppressor gene SOCS1 and acute myeloid leukemia. Oncol Rep. 2018 Aug 1;40(2):1008-16.

77. Liu T-C, Lin S-F, Chang J-G, Yang M-Y, Hung S-Y, Chang C-S. Epigenetic alteration of the SOCS1 gene in chronic myeloid leukaemia. Br J Haematol. 2003;123(4):654-61.

78. Antequera F, Boyes J, Bird A. High levels of De Novo methylation and altered chromatin structure at CpG islands in cell lines. Cell. 1990 Aug 10;62(3):503-14.

\section{Figures}

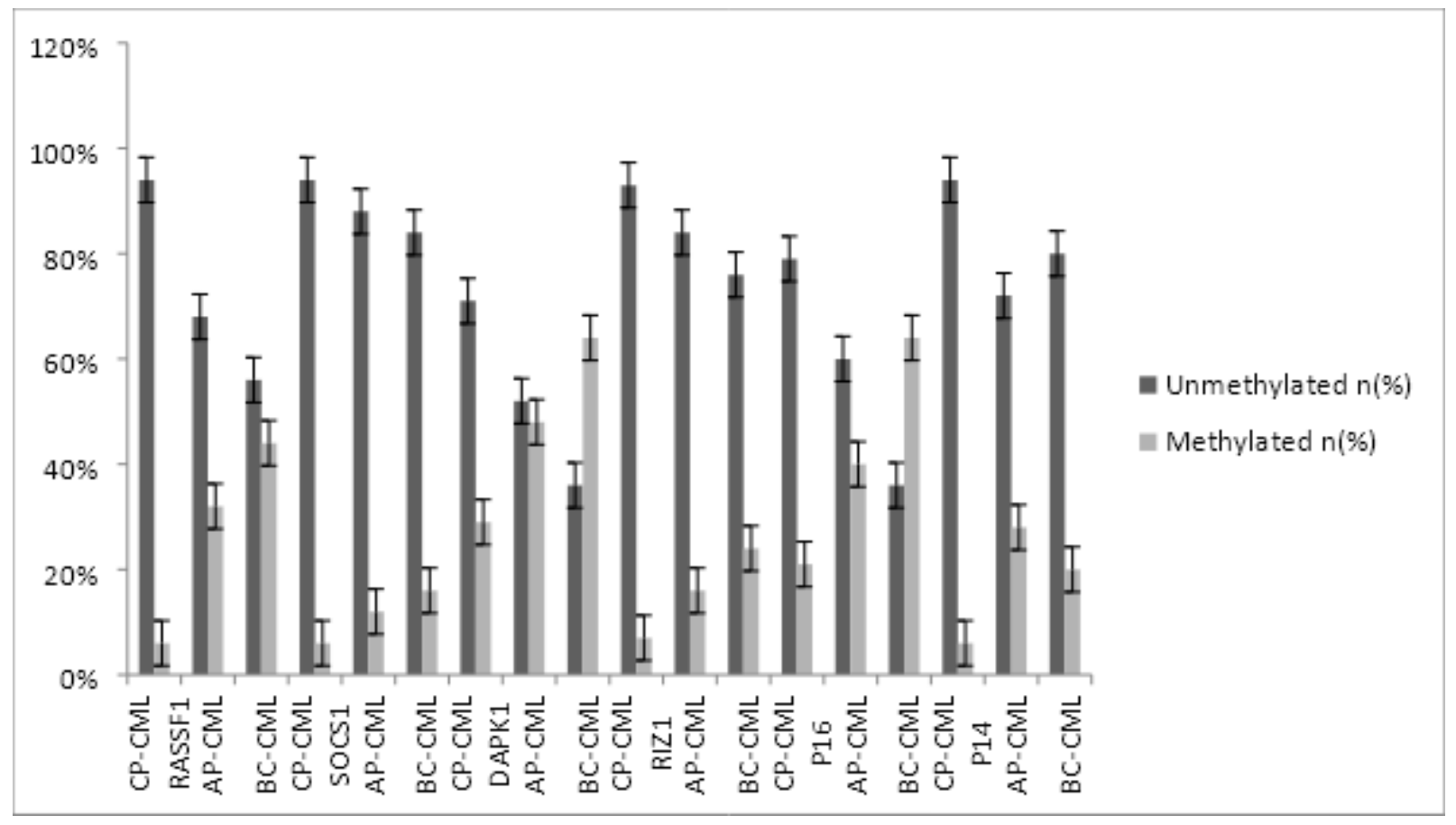

\section{Figure 1}

Frequency of $\mathrm{CpG}$ dinucleotide hydroxymethylation of different genes among CML patients in different clinical stages of the disease. 


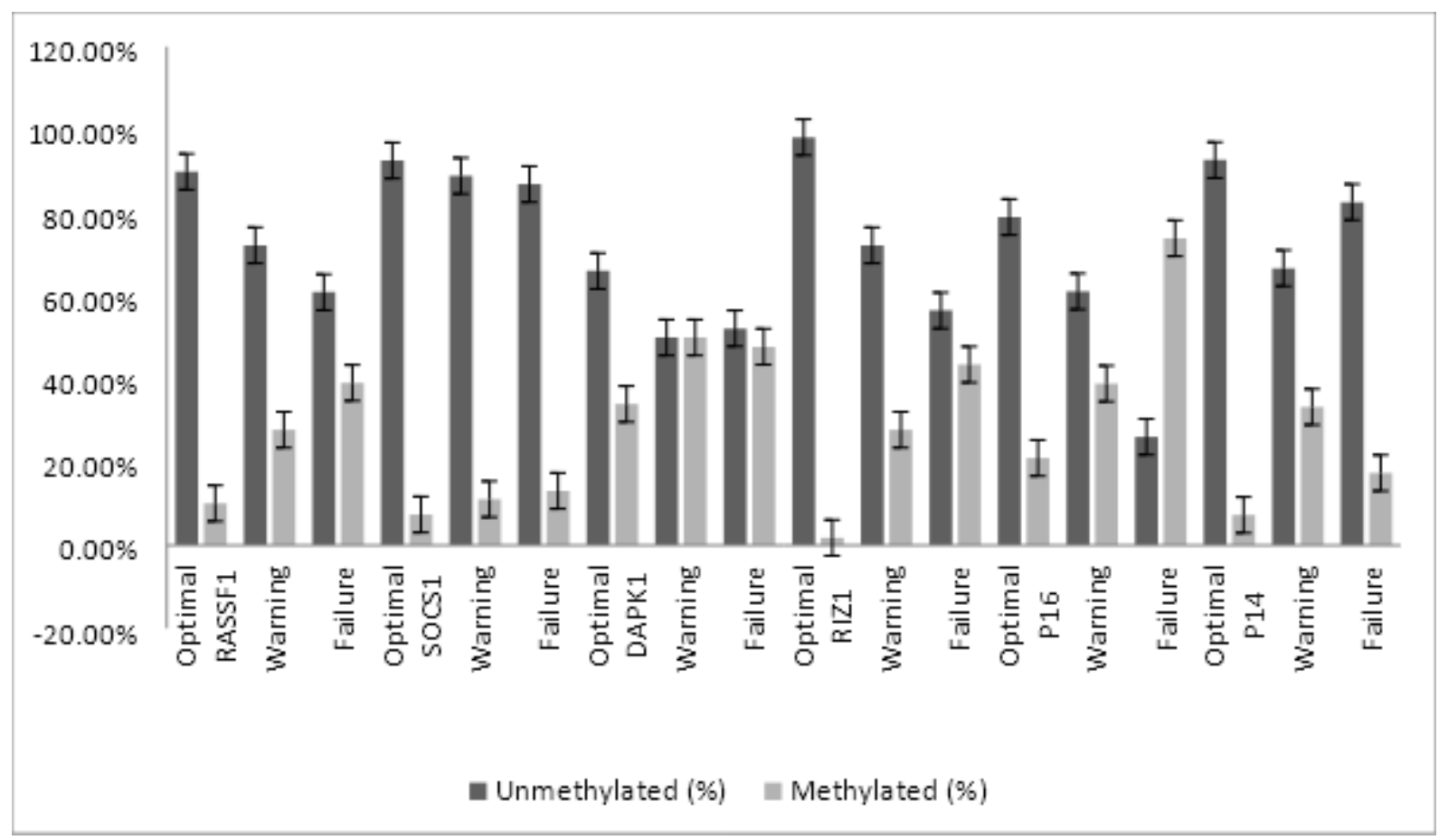

Figure 2

Frequency of $\mathrm{CpG}$ dinucleotide hydroxymethylation of different genes among $\mathrm{CML}$ patients in different imatinib response categories. 

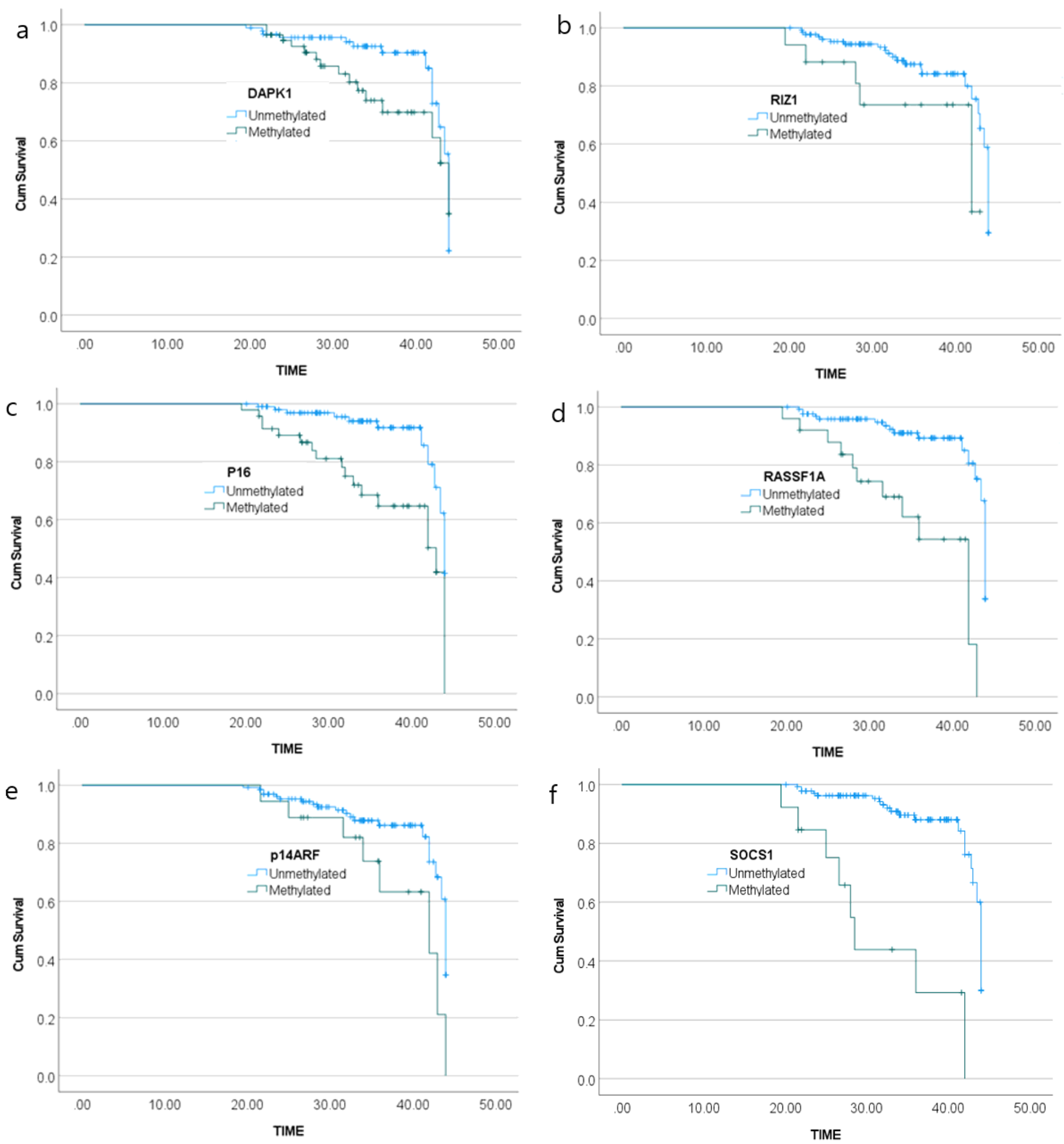

\section{Figure 3}

Survival analysis in concert with promoter hydroxymethylation of cell cycle regulating and apoptosis related genes in CML patients. 